\section{Susien paikat. Ihminen ja susi 1900-luvun Suomessa}

Väitöstilaisuuden Lectio Praecursoria Turun yliopisto 18.1.2020

\author{
HETA LÄHDESMÄKI \\ Yleinen historia ja kulttuuribistoria \\ Turun yliopisto \\ hailah@utu.fi
}

Susi on tämän päivän Suomessa yksi poliittisimmista, yksi eniten tunteita ja keskustelua herättävistä muunlajisista eläimistä. Viime aikoina on julkisessa susikeskustelussa käsitelty muun muassa susien levittäytymistä ja vakiintumista läntiseen Suomeen ja viime vuonna päivitetty susikannan hoitosuunnitelma on myös herättänyt keskustelua. Laajemmin susien suojelu ja siitä johtuva ihmisten toiminnan rajoittaminen puhuttaa, ja siitä, miten yksittäisten ihmisten tai kokonaisen yhteiskunnan tulisi susien kanssa toimia, ei ole yhtenäistä näkemystä. Jos tämän päivän susikeskustelua seuraa, tulee nopeasti selväksi, etteivät nämä kaksi lajia tule ongelmitta toimeen. Kulttuurihistorioitsijana minua kiinnostaa selvittää, miksi näin on?

Historioitsijana koen, että nyky- päivän lisäksi meidän on katsottava menneisyyteen, jotta saisimme vastauksia tähän kysymykseen. Ensimmäiset sudet tulivat nykytiedon valossa nykyisen Suomen alueelle viimeisimmän jääkauden jälkeen. Ihmisellä ja sudelle on siis pitkä yhteinen historia Suomessa. Silti tietämyksemme ihmisen ja suden suhteen historiasta on puutteellista - parhaiten nykypäivän Suomessa tiedetään ja eniten muistellaan 1800-luvun lastensurmatapauksia ja susikannan romahdusta 1800-luvun lopulla.

1900-luvun osalta julkisessa susikeskustelussa esiin nousevat lähinnä susien poissaolo kannan romahtamisen jälkeen ja lajin palaaminen Suomen luontoon vuosisadan lopulla sekä 1990-luvulla tiukentuneen suojelun tuomat haasteet, jotka ovat edelleenkin läsnä. 1900-lukua 
ja varsinkin vuosisadan loppua käsitteleviä tutkimuksia on tehty eri aloilla, ja itsekin tutkin pro gradu -tutkielmassani 1990-luvun loppua ja Suomen EU-jäsenyyden myötä tiukentuneen suojelun alkuvaiheita. Silti pitkään on puuttunut nimenomaan 1900-lukuun pureutuva, ihmisen ja suden suhteeseen keskittyvä ja sitä laaja-alaisesti tarkasteleva tutkimus. Väitöskirjatutkimusta aloittaessani lähdin rehvakkaasti täyttämään tätä tutkimusaukkoa. Tarkasteltava aika oli pitkä ja aihe laaja, mutta onneksi rajasin pian tutkimukseni keskittymään paikkoihin.

Aloin tutkia susien paikkoja 1900-luvun Suomessa, eli sitä, millaista susien fyysinen sijainti tuolloin oli ja miten sijaintiin liittyvät mielikuvat ja käsitykset muotoutuivat, muuttuivat tai tulivat haastetuiksi. Halusin myös tietää, miksi susien paikat ovat olleet sellaisia kuin olivat. Paikkaan keskittyminen tuntui tärkeältä. Menneisyyden, mutta myös nykypäivän haas-

Kuva 1: Alkuperäisaineistossa oli susien esiintymistä kuvaavia karttoja. Tämä kuvasi susien vähimmäiskannan tiheyttä vuonna 1993. Läbde: Nybolm (1995) Suomen suurpetokannat vuosina 1991-93. Riistantutkimusosaston tiedote 135, 9.

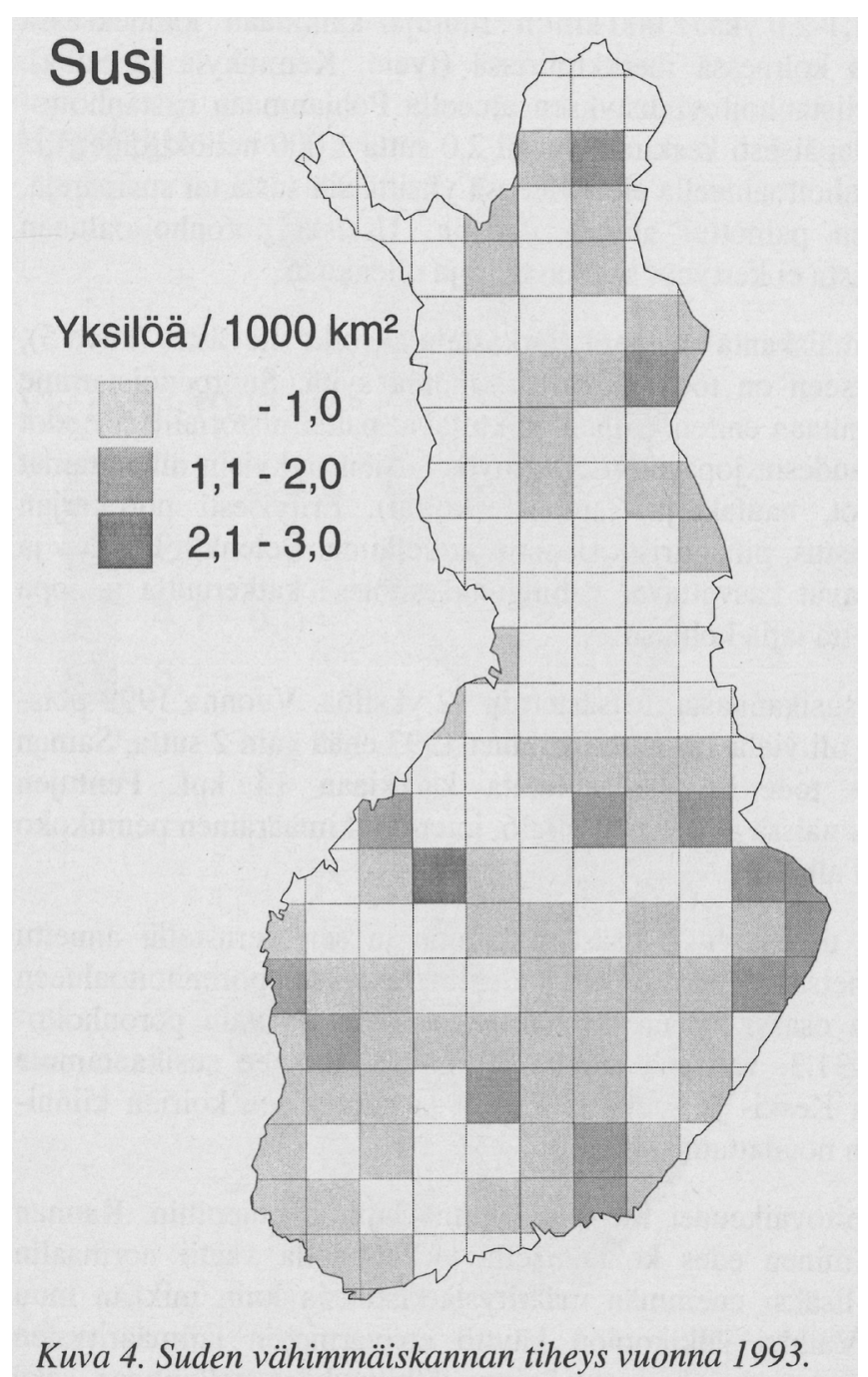


teet liittyvät mielestäni pohjimmiltaan paikkoihin: "susivahingot" eli susien vääränlaiseksi koettu saalistus tapahtuu aina jossakin tilassa, ja myös pelkkä susiyksilön läsnäolo jossakin paikassa koetaan helposti ongelmalliseksi paikkaan liittyvien mielikuvien takia. Myös rauhanomainen tai jollakin tapaa onnistunut kanssakäyminen ihmisen ja suden välillä nivoutuu paikkaan.

Lähdin määrittämään paikan käsitettä uuden eläinmaantieteen edustajien tapaan. Heille eläinten paikat liittyvät sosiaaliseen ja tilalliseen järjestykseen: ihmiset mieltävät tietyt paikat fyysisessä todellisuudessa tietyille eläimille "sopiviksi paikoiksi", mutta eläimet asetetaan myös diskursiivisesti abstrakteihin ja mentaalisiin paikkoihin ja tiloihin ihmisen mielensisäisessä maailmassa. Eläinten paikat liittyvät myös eläinten itse valitsemiin konkreettisiin elinpaikkoihin.

Selvittääkseni susien paikkoja ja niiden muotoutumista aloin tarkastella lainsäädäntöä, tilastoja, riistanhoitoon ja -tutkimukseen liittyvää aineistoa, kuten susikantaa ja susivahinkoja käsitteleviä raportteja ja mietintöjä sekä riistantutkimuksen selvityksiä ja tiedotteita. Kävin läpi myös sanoma- ja aikakauslehtiä sekä eläintieteellistä kirjallisuutta. Lisäksi hyödynsin metsästyskirjallisuutta, eläineettisiä kirjoituksia ja vuosisadan lopulla tehtyjä mielipidetutkimuksia. Alkuperäisaineistoni koostui monista erilaisista lähdetyypeistä, jotka ovat lähinnä kirjal- lisia. Erilaisten tekstien lisäksi aineistossa oli esimerkiksi lehdissä julkaistuja valokuvia sekä pila- ja sarjakuvia, ja karttoja ja kaavioita, joita julkaistiin esimerkiksi eläintieteellisissä kirjoissa ja riistantutkimuksen tiedotteissa.

Paikan lisäksi olin kiinnostunut vallasta. Pro gradu -tutkielmassani olin tutkinut valtaa ihmisen ja suden suhteessa ja väitöskirjassanikin halusin aluksi tarkastella susien paikkoja ja paikkojen muotoutumista nimenomaan vallan kautta. Tämä tuntui loogiselta - olihan kyse kahdesta lajista, jotka molemmat voi tulkita vallankäyttäjiksi ja joiden keskinäinen suhde on usein hierarkkinen. Ihmisten voi tulkita käyttävän valtaa määritellessään susien paikkoja, metsästäessään tai suojellessaan susia, kerätessään niistä tietoa, kirjoittaessaan susista ja luodessaan, toistaessaan tai kumotessaan susia koskevia mielikuvia. Susien taas voi ajatella käyttävän valtaa esimerkiksi saalistaessaan ja tullessaan johonkin tilaan, kuten laitumelle.

Pian havahduin siihen, ettei valtasuhteeseen keskittyminen tai vain siihen jääminen ollut mielekästä. Näkökulma ei tuntunut tuovan mitään uutta esille kahden lajin välisestä suhteesta. Lisäksi koin, että valtaan keskittyminen tekisi tutkimuksesta konfliktikeskeistä; halusin kirjoittaa lajienvälisestä suhteesta ongelmia vähättelemättä, mutta niitä myöskään liikaa painottamatta. Tavoitteeni oli ymmärtää menneisyyden ihmisiä ja susia, ja 
sitä kautta ymmärtää myös tämän päivän susisuhdetta.

Aloin kiinnostua toimijuudesta. Siinä, että suden tulkitsee toimijaksi, ihmisiin ja muihin olentoihin vaikuttavaksi olennoksi, ei ole sinällään mitään uutta; joissakin aiemmissa suomalaisissa susihistoriantutkimuksissa susi on esitetty liikaakin ihmisten elämään vaikuttavana toimijana. Kiinnostuin uusmaterialistisista tavoista määritellä toimijuus suhteissa toimimiseksi, yhteistoiminnaksi ja yhteistyöksi tai vastavuoroiseksi kanssakäymiseksi. Tällaisen ajattelun mukaan toimijoita ollaan aina suhteessa muihin ja muiden kanssa, ei siis ikään kuin etukäteen tai absoluuttisesti. Aloin määritellä tutkimuksessani toimijuuden tällä tavoin, ihmisen ja suden suhteessa ilmenneeksi kanssakäymiseksi ja yhteistoiminnaksi. Tällöin en ikään kuin etsisi syyllisiä, vaan kiinnittäisin huomiota kanssakäymiseen. Koin tieteentutkija Donna Harawayn yhdessämuotoutumisen ja yhdessä-tulemisen käsitteet hyödyllisiksi. Niiden kautta hahmotin sen, että susien paikkojen muotoutuminen muokkasi ja uudisti molempia lajeja ja niiden käyttäytymistä - ja vaikutti myös muihin lajeihin kuten poroihin, koiriin ja hirviin. Fyysikko, filosofi, Karen Baradin ajatukset materian ja merkityksen yhteenkietoutumisesta avasivat myös uusia maailmoja. Baradin ajattelu auttoi näkemään susien paikkojen olevan materiaalis-diskursiivisesti syntyneitä: esimerkiksi lehtien sivuilla luodut tai vah- vistetut mielikuvat vaikuttivat todellisiin susiin ja niiden elämään ja kuolemaan, ja myös sudet ottivat osaa mielikuvien syntymiseen esimerkiksi käyttäytyessään mielikuvaa vahvistavalla tai sitä kumoavalla tavalla.

Toimijoiden lisäksi olin kiinnostunut tarkastelemaan ihmisten lisäksi susia historiallisina subjekteina, eli olentoina, joilla on tavoitteita sekä motivaatiota ja jotka kykenevät saamaan aikaan muutosta ja historiallisia tapahtumia yksin ja yhdessä muiden toimijoiden kanssa. Tämä pyrkimys johdatti minut pohtimaan susien näkökulmaa. Tällä tarkoitan työssäni susien mahdollisia intentioita, kokemuksia ja tunteita. Lähdin pohtimaan susien näkökulmaa biologian ja etologian eli eläinten käyttäytymistieteen tutkimustulosten avulla. Tässä asiassa koin olevani uuden äärellä: monissa aiemmissa susihistorian tutkimuksissa suhdetta on tarkasteltu pitkälti vain ihmisen näkökulmasta.

Susien näkökulman pohtiminen ei tarkoittanut sitä, että olisin unohtanut ihmisen: pohdin ihmisten ja eri ihmisryhmien, kuten susialueilla elävien ihmisten, metsästäjien, poromiesten, riistantutkijoiden, viranomaisten ja luonnonsuojelijoiden näkökulmaa. Tarkoitukseni ei myöskään ollut inhimillistää susia. En kuitenkaan halunnut vähätellä susia: susi on nykykäsityksen mukaan hyvin älykäs, ongelmia ratkaiseva ja toimintaansa tiedostava eläin. Susien näkökulman pohtimista voi myös pitää posthumanistisena pyrki- 
myksenä. Olemme tottuneet kuulemaan tarinoita, joissa vain ihmiset voivat olla päähenkilöitä. Kriittisessä posthumanismissa tämä haastetaan.

Tutkimuksessani sain selville susien fyysistä sijaintia kuvaavien mielikuvien syntyneen, voimistuneen ja tulleen haastetuiksi lajienvälisessä suhteessa, erilaisten ihmisryhmien ja susien toimesta. Molemmat lajit vaikuttivat myös siihen, millainen susien fyysinen sijainti kulloinkin oli. ajoin, olivat määrät huomattavasti pienempiä kuin ennen kannanromahdusta. Ajan myötä susien vähälukuisuus muuttui normiksi. Susien vähälukuisuus ei kuitenkaan johtunut susien ihmisistä riippumattomasta valinnasta pysyä poissa, sillä ihmiset tappoivat susirajan väärälle puolelle tulleita susia. Näin kävi esimerkiksi Liedossa loppuvuonna 1920 ja Hämeen seudulla 1950- ja 1970-lukujen alussa liikkuneille susille. Näiden susien sijoittumisen ei-toivottavuus ilmeni tavoissa, joilla

Väitöskirjatyön edetessä, lähteitäni lukiessa, kiinnostuin erilaisista mielikuvista, joista yksi oli käsitys susirajasta, maan halkovasta rajasta. Aineistoissani todettiin epäsuorasti tai joskus hyvinkin suoraan, että kuvitteellisen rajan itä- ja pohjoispuolella oli susien "normaalia" elää, kun taas tietyille alueille tulleet sudet olivat poissa paikaltaan. Tulkitsin susirajan syntyneen 1900-luvun aikana lajienvälisen, ajoittain väkivaltaisen yhteistyön tuloksena: käsitys susirajasta vaati tulkintani mukaan sen, että sudet olivat vähälukuisia tietyissä osissa maata. Historiallisen tiedon mukaan susia eli ennen 1800-luvun lopulla tapahtunutta kannanromahdusta lähes kaikkialla Suomessa. Vaikka susia nähtiin susirajan "väärällä" puolella 1900-luvulla aika

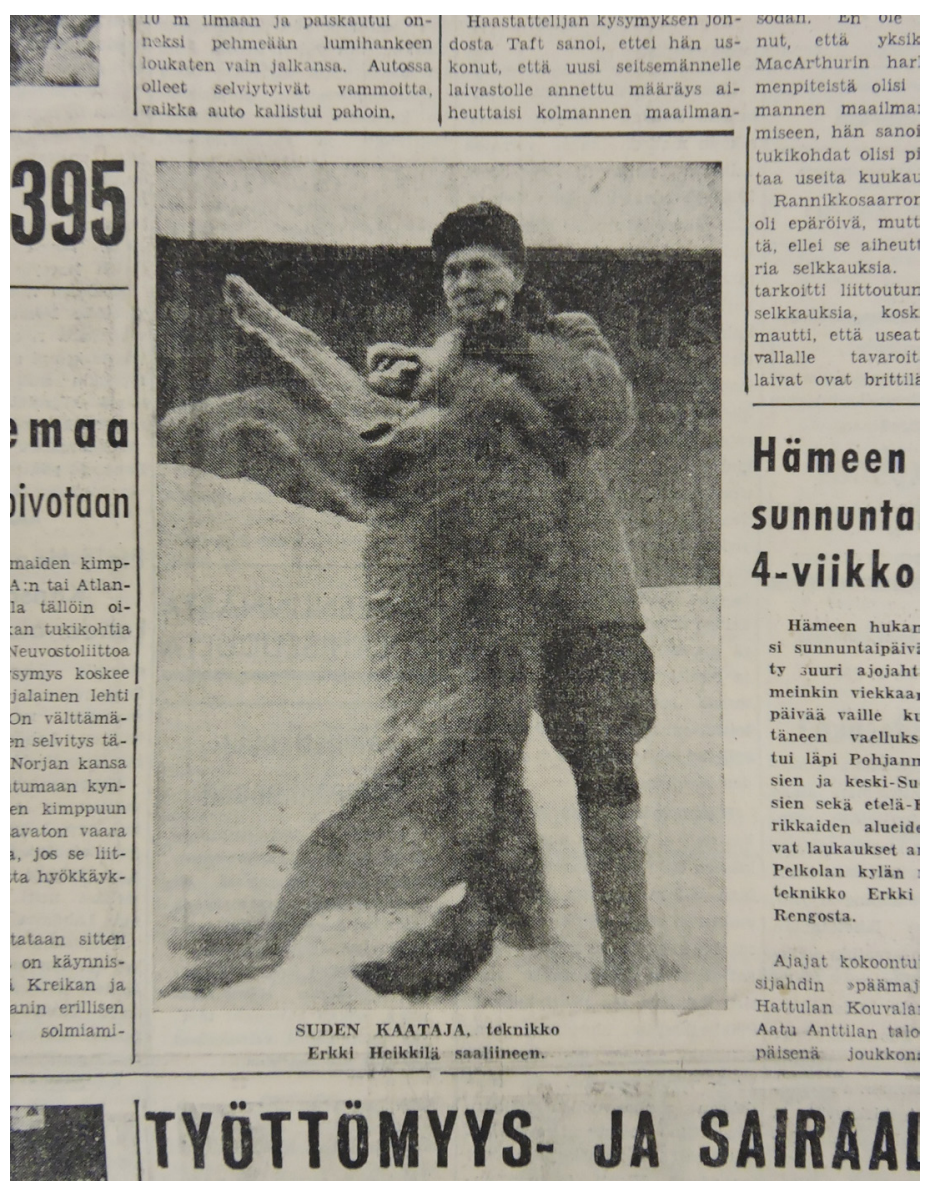

Kuva 2: "Susirajan" väärällä puolella, Hämeen seudulla alkuvuonna 1953 tavattu susi tapettiin helmikuussa ison jabdin päätteeksi. Lähde: Hämeen susi tapasi kohtalonsa sunnuntaina Hattulan metsässä 4-viikkoisen ajojabdin jälkeen, Hämeen Sanomat 10.2.1953, 1. 
näitä susia kohdeltiin ja siinä kuinka niistä kirjoitettiin: ne yritettiin saada hengiltä yleensä heti havaituksi tultuaan ja niiden sijoittumisesta kirjoitettiin kielteiseen tai inmettelevään sävyyn. Näin materia eli sudet ja merkitys eli mielikuvat lomittuivat yhteen.

Susiraja-mielikuva on edelleenkin voimassa. Nykyään suurin osa Suomessa elävistä susista elää läntisessä Suomessa. Tätä voidaan pitää outona, jopa epänormaalina tilanteena susiraja-mielikuvan ta-

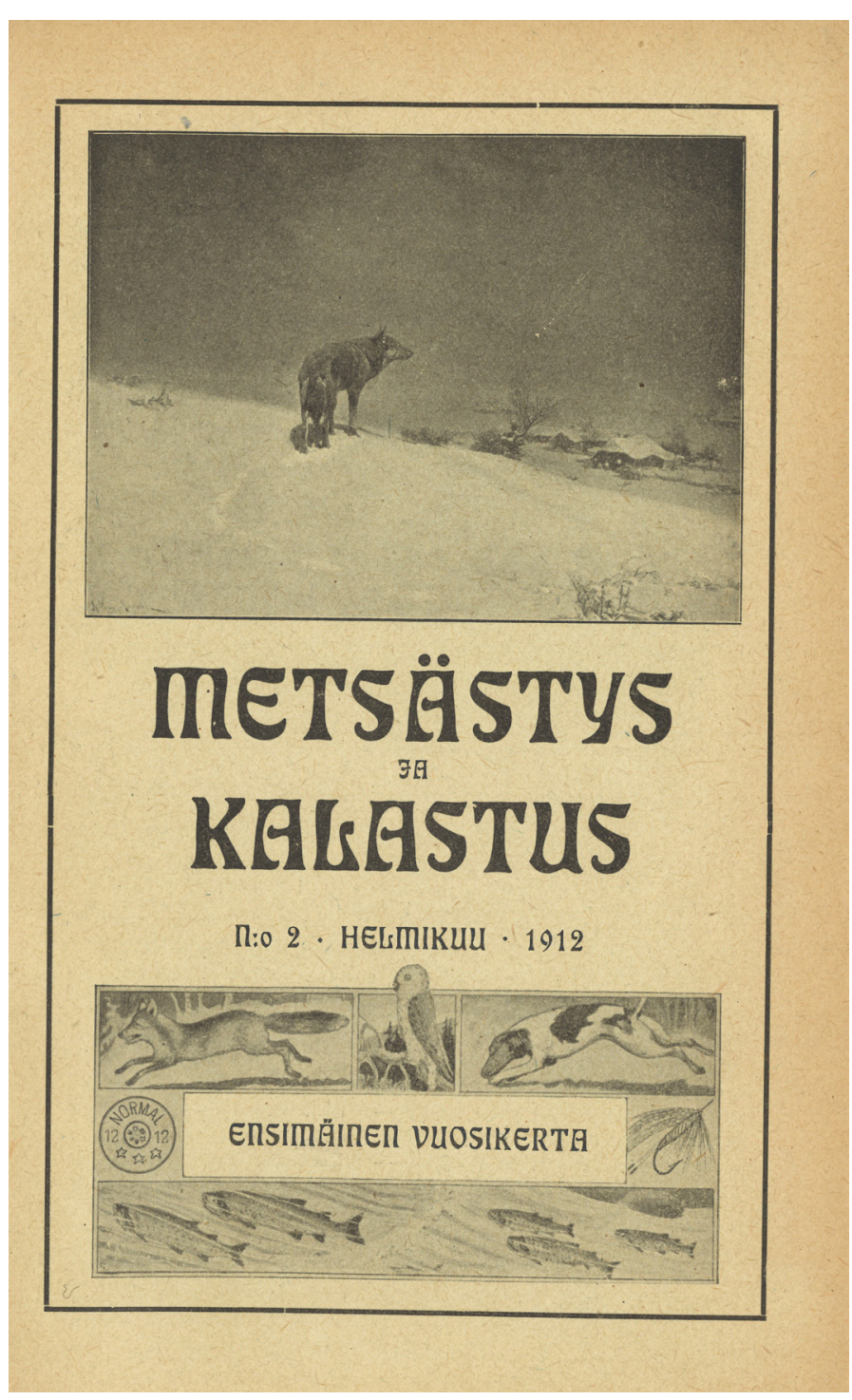

kia. Sitä voidaan myös käyttää argumenttina susien tappamisen oikeuttamiseksi. Aineistoni kuvaamat sudet kuitenkin kertovat susille olleen tavallista tulla näille alueille. Vaikka susien oli mahdollista elää pysyvämmin näillä alueilla vasta tiukentuneen suojelun myötä, yrittivät sudet aineistojeni valossa elää alueilla aiemminkin.

Tarkastelin myös susien liikkumista ja elämistä suhteessa ihmisen elinpiiriin. Aineistojeni mukaan sudet ovat liikkuneet lähellä ihmisiä, ja läheisyydestä on voinut olla niille hyötyä esimerkiksi ravinnonsaannin kannalta. Kuitenkin mielikuvat sudesta erämaalajina ja pihoilla käyvistä susista häirikkösusina ovat nykyään vahvasti voimassa. Lähdin tutkimaan näitä käsityksiä ja havaitsin myös niiden syntyneen Suomessa vasta 1900-luvun aikana. Vielä vuosisadan alussa esitettiin susien tuleminen ihmisten lähelle osin ikävänä mutta tavallisena asiana; eläintietokirjojen ja

Kuva 3: 1900-luvun alkupuolen kuvituskuvissa susi kuvattiin ibmisen läbelle, kulttuurimaisemaan tulevana lajina. Metsästys ja Kalastus -lehden belmikuun numeron kannessa komeili jäljennös puolalaisen taiteilijan Alfred von Wierusz-Kowalskin vuonna 1900 maalaamasta Samotny Wilk eli Yksinäinen susi -nimisestä maalauksesta. Lähde: Metsästys ja Kalastus 2/1912, kansi. 
sanomalehtien mukaan susilla oli tapana tehdät niin erityisesti talvisin. Kylien ja kaupunkien keskustaan sekä pihoihin tulevia susia kutsuttiin rohkeiksi, eikä tällaista sijoittumista pidetty hyvänä asiana, mutta sitä ei lähteissäni epänormaalisoitu tai epäluonnollistettu. Vuosisadan puolivälissä sanomalehtikirjoittelussa ilmeni muutos. Ihmisten lähelle tulleista susista tuli röyhkeitä ja vuosisadan lopulla häirikkösusia, ja samalla suden paikka siirtyi kuvitteelliseen erämaahan, pois ihmisen luota. samalla susien tietty sijoittuminen epänormalisoitiin ja sitä kautta voitiin oikeuttaa ihmisten lähelle tulevien susien tappaminen aikana, jolloin susi lajina oli suojeltu.

Myös erämaalaji-mielikuva näytti syntyneen ihmisen ja suden yhteistyönä, ja tulkitsin myös susien vaikuttaneen sen syntymiseen: susia eli 1900-luvun Suomessa vähemmän kuin esimerkiksi runsassusisella 1800-luvulla, joten susiakin vieraili ihmisten luona vähemmän kuin aiemmin, ja hiljalleen vahvistui käsitys siitä, että sudet elävät erämaisessa luonnossa ja jopa tarvitsevat sitä elääkseen. Sudet ovat voineet toimia mielikuvaa vahvistavalla tavalla: pysymällä inmisistä kauempana, ne ovat voineet välttää tapetuksi tulemisen. Näin erämaalaji-mielikuvakin kertoo materian ja merkityksen lomittumisesta.

Väitöskirjassani selvitin myös susien liikkumista Suomen valtion rajojen yli sekä susien esiintymistä ihmisen ja saalis- eläinten elinpiireissä. Aineistoissani kerrottiin myös väkivallattomista keinoista sopeutua elämään susien kanssa ja selvitin 1970-luvulla alkaneen susien suojelun historiaa. Havahduin siihen, että jo ennen suojelun alkamista ihmiset saattoivat suhtautua yllättävän ymmärtäväisesti susien saalistamiseen ja miettiä sitä susien näkökulmasta. Löysin susia puolustavia äänensävyjä aineistostani 1900-luvun puolivälistä lähtien. Hiljalleen syntyi monien luonnonsuojelijoiden, metsästäjien, riistantutkijoiden ja viranomaisten jakama käsitys Suomessa elävistä susista suomalaisina, maahan kuuluvina susina.

Havahduin myös siihen, ettei susien tappaminen aineistojeni valossa näyttäytynyt niin tehokkaana keinona ratkaista kahden lajin välisiä ongelmia kuin mitä edelleenkin ajatellaan. Tappaminen - myös rajoittamaton tappaminen - ratkaisi ongelmia vain tilapäisesti. Tästä kertoo esimerkiksi "susivahinkojen" korvauskäytännön syntyminen 1900-luvulla ja muut tavat sopeutua susien läsnäoloon: maksamalla korvauksia, rakentamalla susiaitoja, suojaamalla metsästyskoiria ja järjestämällä koulukyytejä yritettiin susien kanssa tulla toimeen.

Väitöskirjassani olen tarkastellut monilajisessa maailmassa elämisen tematiikkaa; sitä, mitä tarkoittaa jakaa oma elintilansa muiden lajien kanssa. Luonto ja villieläimiksi luokitellut eläimet eivät ole meidän täysin hallittavissamme. Vaikka Suomen 
kaltaisessa länsimaassa pystymme kontrolloimaan monia asioita elämässämme, tulee vastaan hetkiä, jolloin maailma $\mathrm{Ba}$ radin sanoin "iskee takaisin", eivätkä asiat pysy hallittuina. Tällaiset hetket, se miten niihin varaudumme ja suhtaudumme, kertovat paljon meistä ihmisinä. Koska elämme maailmassa yhdessä lukemattomien eri elämänmuotojen kanssa, ei historiantutkimuksenkaan tule olla vain ihmiskeskeistä, vaan ottaa huomioon myös muut elämänmuodot. Lajikadon kiihtyessä, luonnonvaraisten eläinlajien yksilömäärien vähentyessä ja ihmisten ravinnokseen ja muuksi hyödyksi kasvattamien eläinyksilöiden määrien kasvaessa on entistä tärkeämpää pohtia elintilan jakamisen haasteita. Jotta voimme ratkaista ongelmia ja yrittää elää tullen toimeen muiden lajien kanssa, tulee meidän tuntea nykyhetkeen johtanut monilajinen menneisyys.

FT Heta Lähdesmäen väitöskirja "Susien paikat. Ihminen ja susi 1900-luvun Suomessa" tarkastettiin Turun yliopistossa 18.1.2020. Vastaväittäjänä toimi FT Jukka Nyyssönen (UiT - Norjan arktinen yliopisto) ja kustoksena professori Marjo Kaartinen (Turun yliopisto). 